\title{
HERMENÉUTICA, ANALOGÍA Y RETÓRICA. ENTREVISTA A MAURICIO BECHOT
}

\author{
Francisco ARENAS-DOLZ \\ Universidad de Valencia
}

RESUMEN. Mauricio Beuchot ha señalado dos líneas extremas en la hermenéutica: una, que podemos llamar hermenéutica univocista, que pretende interpretar con toda claridad y distinción, para alcanzar una única interpretación como válida; $y$ otra, que admite como válida casi cualquier interpretación, llegando a un relativismo insostenible. Frente a ellas conviene establecer una línea intermedia, que podemos llamar hermenéutica analógica. En este artículo ofrecemos una presentación resumida de los elementos fundamentales de la hermenéutica analógico-icónica de Mauricio Beuchot a través de una entrevista con el filósofo mexicano.

Tra chiaro e oscuro c'è un velo sottile.

Tra buio e notte il velo si assotiglia.

Tra notte e nulla il velo è quasi impalpabile.

La nostra mente fa corporeo anche il nulla.

$\mathrm{Ma}$ è allora

che cominciano i grandi rovesciamenti, la furiosa passione per il tangibile, non quello elefantico, mostruoso che nessuna mano può chiudere in sé, ma la minugia, il fuscello che neppure il più ostinato bricoleur può scorgere.

(E. Montale, 1973: "Tra chiaro e oscuro", Diario del '72, en Tutte le poesie, Milán 1984). 
El Señor Ibrahim (Francia 2003), una película de François Dupeyron, protagonizada por Omar Sharif, es una película sobre el ser humano, sobre el intercambio, que busca las confluencias. Momo, un niño judío de trece años, abandonado a su suerte, tiene un amigo, uno sólo, Monsieur Ibrahim, el tendero árabe de la calle Azul. Pero las apariencias engañan: ni la calle Azul es azul ni el árabe es árabe. Y la vida no tiene por qué ser siempre triste... El hecho de que uno sea judío y el otro musulmán no tiene mayor importancia, la relación siempre habría sido la misma. Este tendero, que filosofa sin saberlo, es un hombre con muchísimo sentido común, una especie de sabio. Ibrahim dice cosas profundas sin que lo parezcan, tiene una forma de hablar que no tiene ningún tipo de pretensiones. Su trabajo le permite pasar el tiempo y contemplar a los transeúntes. El muchacho, Momo, que nunca ha hablado con nadie, puesto que nadie se ha dirigido nunca a él, encuentra en Ibrahim a un hombre que le enseña cosas raras a priori. Sin embargo, Momo piensa que la manera de actuar de Ibrahim es muy hermosa, por eso deduce que lo que dice tiene también que ser hermoso. Aprende a confiar en él, en su logos, en la prosa rimada y en la verdad revelada en su Alcorán.

\section{Proemio}

Las referencias que anteceden y que concluyen este texto ubican de alguna forma los temas fundamentales y la sensibilidad hermenéutica de Mauricio Beuchot. Por una parte, la búsqueda de una configuración intermedia del logos entre el univocismo moderno y el equivocismo posmoderno: la analogia; por otra parte, el hallazgo de un signo que nos lleve del fragmento al todo, "entre claro y oscuro", respetando la individualidad y la diferencia: el icono.

Este texto recoge las conversaciones mantenidas con Mauricio Beuchot, a través de las cuales podemos tener una idea resumida pero muy completa de la propuesta del filósofo mexicano: la hermenéutica analógico-icónica. Las conversaciones presentadas en este artículo son fruto del diálogo mantenido en el Centro de Estudios Clásicos del Instituto de Investigaciones Filológicas de la Universidad Nacional Autónoma de México (UNAM) entre febrero y junio de 2002, así como a través del correo electrónico durante el mes de agosto de 2004. Han sido ligeramente retocadas y completadas y constituyen una presentación sucinta de la filosofía de Mauricio Beuchot. En este sentido, es de agradecer que el mismo Mauricio Beuchot, al hablar de su pensamiento y responder a las pre- 
guntas planteadas, pone en juego, quizá con mayor nitidez, lo dicho en sus libros y se somete a la prueba del instante de un interlocutor que, si bien no le invita a expresarse sobre temas distintos de los que había tratado ampliamente en sus libros, busca aclaraciones inéditas.

Es de agradecer la propuesta de Teresa Oñate y Cristina García Santos de publicar unas páginas sobre el pensamiento de Mauricio Beuchot. También las conversaciones con Mario Biamino, Víctor Hugo Méndez Aguirre, José Manuel Orozco Garibay, José Luis Ramírez, Edna Rodríguez Vizcaíno y Vicente Esteve enriquecieron notablemente estas líneas. La redacción final del texto tuvo lugar en varios escenarios. La distancia, sin embargo, no ha supuesto ninguna dificultad para redactar este trabajo, gracias a la amabilidad de Mauricio Beuchot.

\section{Mauricio Beuchot, una hermenéutica del lógos}

Mauricio Beuchot Puente nace en Torreón (Coahuila, México) el 4 de marzo de 1950. Es una de las figuras más relevantes del pensamiento mexicano. Investigador en el Centro de Estudios Clásicos del Instituto de Investigaciones Filológicas de la UNAM, después de haberlo sido en el Instituto de Investigaciones Filosóficas de la misma universidad. De 1961 a 1968 realizó en México estudios de Humanidades Clásicas y de 1968 a 1973 estudió Filosofia. Entre 1973 y 1974 llevó a cabo estudios de Filosofía en la Universidad de Friburgo, Suiza. Licenciado en filosofía por el Instituto Superior Autónomo de Occidente (actualmente Universidad del Valle de Atemajac), Guadalajara, Jalisco, México. Los estudios los realizó de 1974 a 1976 y, en ese mismo año, obtuvo el grado con mención honorífica. La tesis que defendió llevaba por título Estructura y función de la metafisica de Aristoteles. La Maestría en filosofía la realizó en la Universidad Iberoamericana de México de 1976 a 1978; en ese mismo año obtuvo el grado de maestro con la tesis Análisis semiótico de la metafisica. En la Universidad Iberoamericana de México, entre 1978 y 1980, realizó los estudios para obtener el grado de Doctor en Filosofía. La tesis con que sustentó su examen, Sobre el problema de los universales en la filosofía analítica y en la metafisica tomista, es considerada un clásico sobre el tema.

Su ingente e innovadora obra le ha valido reconocimiento internacional. Desde 1980 hasta la actualidad ha dirigido y formado parte del consejo de redacción de numerosas publicaciones. 
El 8 de febrero de 1990 fue nombrado coordinador del Centro de Estudios Clásicos del Instituto de Investigaciones Filológicas de la UNAM. Este cargo lo desempeńó hasta 1996 - después de que el 19 de diciembre de 1993 fuera electo para el cargo señalado por segunda vez-.

Es miembro de la Academia Mexicana de la Historia (1990), de la Academia de Doctores en Humanidades (1996), de la Sociedad Cultural Sor Juana Inés de la Cruz (1996), de la Academia Mexicana de la Lengua (1998), de la Academia Romana de Santo Tomás de Aquino (1999) y de la Academia Mexicana de los Derechos Humanos (2000).

Su bibliografía rebasa ya los cincuenta títulos de libros y más de un centenar de colaboraciones y artículos. Ha traducido además a autores como Alberto Magno, Juan de Santo Tomás, Tomás de Mercado, Alfonso de la Vera Cruz, Leibniz, y un grupo escolástico de autores novohispanos. La influencia de su pensamiento se refleja también en varias tesis consagradas a su obra y en más de veinte estudios críticos sobre la misma.

La traducción del latín de pensadores novohispanos convierte a Mauricio Beuchot en uno de los más profundos conocedores de esta época del pensamiento. Su estudio sobre los universales le permitió entablar un diálogo profundo con el nominalismo y con lo que, en el siglo XX, desembocaría en la filosofía del lenguaje. Este análisis desembocó en la propuesta hermenéutica que Mauricio Beuchot ha desarrollado en los últimos años, la hermenéutica analógico-icónica. Con ella Mauricio Beuchot intenta abrir un camino para un diálogo que rompa la incomensurabilidad y el relativismo. La hermenéutica analógica de Mauricio Beuchot es una hermenéutica del lógos (limitado) del hombre. Es decir, Mauricio Beuchot cree que el hombre puede decir algo del mundo. Pero es consciente de que ese decir es limitado. Sin embargo, no se deja avasallar por esos límites, sino que es capaz de reconocer que, a pesar de ellos, es posible hablar con sentido y que, por ello, al hablar se crean compromisos, se asumen posturas, se toma partido.

La intención más profunda de la hermenéutica analógica de Mauricio Beuchot se encamina hacia la toma de conciencia del compromiso ético que el hablar y el decir suponen. El lenguaje es una herramienta limitada, sin embargo puede tocar la verdad, el ser $y$, además de ello, funda sentidos $\mathrm{y}$, por consiguiente, modos de vida. Así, la hermenéutica analógico-icónica de Mauricio Beuchot apunta a 
una clarificación y vivencia de la eticidad que cubre todas las dimensiones humanas, incluyendo el lenguaje de una manera sorprendente. Esta dimensión ética estaba presente en la filosofía antigua, medieval. Allí radica la recuperación del pensamiento antiguo en la propuesta de Mauricio Beuchot.

\section{Años de aprendizaje}

Francisco Arenas-Dolz: ¿Podrías narrar brevemente tus años de aprendizaje y cuál ha sido tu itinerario intelectual?

Mauricio Beuchot: En mis años de aprendizaje me entrené en la filosofía griega y medieval, principalmente la tomista. También, de manera muy intensa, en la filosofía analítica. En una estancia de estudios en Friburgo (Suiza) entre 1973 y 1974 , tuve de profesores a I. M. Bochenski y a Guido Küng. Del primero heredé el gusto por la historia de la lógica y de la filosofía del lenguaje, así como el reconocimiento de la importancia de Ch. S. Peirce; del segundo, el problema de los universales, es decir, el aprecio por la ontología. Por eso, mi tesis de doctorado, que presenté en 1980 en la Universidad Iberoamericana (México, D.F.), fue sobre el problema de los universales en la historia y su desembocadura en la filosofía analítica. Eso me ha hecho ver siempre, en seguimiento de W. Quine, que en el lenguaje hay una remisión muy fuerte a la ontología. Me quedó esa impresión de que la ontología es ineludible.

Enseñé primero en la Universidad Iberoamericana, en 1976, semiótica y filosofía del lenguaje, y luego, en 1979, en la Facultad de Filosofía y Letras de la Universidad Nacional Autónoma de México (UNAM), en cuyo posgrado daba el curso de historia de la lógica. Ese mismo año de 1979 entré como investigador en el Instituto de Investigaciones Filosóficas de la UNAM, donde me dediqué a la historia de la lógica y de la filosofía del lenguaje, principalmente en los medievales y coloniales. La misma filosofia del lenguaje me fue llevando a la hermenéutica, y, después de once años, en 1991, se me invitó al Instituto de Investigaciones Filológicas de la misma UNAM, de cuyo Centro de Estudios Clásicos fui coordinador dos periodos, es decir, casi ocho años. En Filológicas se utilizaba mucho la hermenéutica, como es natural, y allí empecé a dedicarme a la hermenéutica. Me pedían que, como filósofo, les hablara a los filólogos de las aplicaciones de la hermenéutica a la filología clásica. Fue así como surgió lo de una hermenéutica analógica. 
Yo ya había trabajado la hermenéutica tanto en Gadamer como en Ricoeur, a quien conocí en un congreso en Granada el año 1987. Me iluminó mucho la discusión que sostuve con él acerca de su aplicación de la hermenéutica al psicoanálisis. En 1989 publiqué un libro sobre Ricoeur y su visión de la acción psicoanalítica. Además, en un excelente libro, La metáfora viva, Ricoeur da una gran importancia a la analogía, y eso me orientó. En 1991 me tocó dialogar, en la Universidad Iberoamericana (México, D.F.), con alguien muy vinculado a la hermenéutica, pero en ese entonces ya más centrado en la pragmática, Karl-Otto Apel, con quien discutí el problema de la referencia y la verdad. Noté un miedo muy fuerte a la referencia, por creer que conduce a una teoría de la verdad como correspondencia y, por ende, a un realismo demasiado fuerte. Traté de meditar sobre estos problemas y, en el Congreso Nacional de Filosofía de 1993, en Cuernavaca (México), presenté un esbozo de mi propuesta de un modelo analógico de interpretación. Fue en el marco de una mesa de discusión muy amplia, con Ambrosio Velasco, Mariflor Aguilar, Raúl Alcalá, Samuel Arriarán y José Manuel Orozco, todos muy queridos amigos. El debate me estimuló, al ver que, aun cuando había - y sigue habiendomuchas cosas que corregir, apuntalar y aumentar, la propuesta había sido bien recibida.

En 1995, tratando de vertebrar más el modelo analógico de la hermenéutica, publiqué el libro Posmodernidad, hermenéutica y analogia. El diálogo se daba ahora con la filosofía posmoderna, así como antes se daba en el ámbito de la filosoffa analítica. Me di cuenta de cómo la posmodernidad, que se inclinaba mucho a la equivocidad, con su gran decepción de la razón, era como una reacción en contra de los positivismos, que se inclinaban mucho a la univocidad, ideal inalcanzable, y que de tiempo en tiempo se derrumbaba. Pero se echaba en falta algo intermedio, por eso había que acudir a aquello que estaba - según la semántica- entre la univocidad y la equivocidad, a saber, la analogía. Por eso se hacía necesaria una hermenéutica distinta, ni univocista ni equivocista, sino analógica. Y fue como desemboqué en el Tratado de hermenéutica analogica, publicado en 1997, en su primera edición.

\section{A vueltas con la analogía}

F.A.: En el Tratado de hermenéutica analógica. Hacia un nuevo modelo de interpretación (México 1997) buscas, en una primera parte, el sentido de una her- 
menéutica analógica y el tipo de argumentación que puede ofrecer, vinculándola con la metafísica y con la ética; en una segunda parte, intentas aplicar la hermenéutica analógica vinculándola con la filología clásica, con el psicoanálisis freudiano y también realizas una comparación de la hermenéutica con la semiótica. ¿Qué tendrías que matizar, añadir o corregir a la segunda edición de tu libro publicada en 2000 ?

M.B.: Primero presento un intento de estructuración de la hermenéutica con el concepto de analogía. Para ello sentí la necesidad de conectarla con la metafísica y con la ética, pues son las disciplinas principales de la filosofia. Algunos discuten cuál de ellas es la primera y cuál la segunda, pero creo que son simultáneas, dada la importancia que tienen. Pero estoy convencido de que la hermenéutica sólo tiene estructuración aceptable por su relación con la ontología o metafísica. Ella es la que le puede señalar su lugar, su alcance y sus límites. Inclusive a través de eso que podríamos llamar reflexión previa (o posterior) a la ontológica, que es la epistemológica. Eso nos conduce a la forma de argumentación que se da en la hermenéutica. Una argumentación no analítica, sino más bien tópica o retórica, del tipo que cultivó tanto Perelman. Y la conexión de la hermenéutica con la ética nos la marca Levinas, quien no dejaba de insistir en que no podemos hacer filosofía ninguna si no tenemos la actitud de respeto por la vida y la dignidad del otro.

Luego vinieron algunas aplicaciones: a la filología clásica, al psicoanálisis y la comparación con la semiótica. La aplicación a la filología era obligada, pues la hermenéutica analógica ha sido aplicada por filólogos, estudiosos de lo clásico, en el Instituto de Investigaciones Filológicas de la UNAM, como el doctor Víctor Hugo Méndez. También ha sido utilizada y aplicada, tanto a la teoría como a la clínica, por varios psicoanalistas, como los doctores Ricardo Blanco, Felipe Flores y Luis Álvarez Colín, de México, D.F. Y la comparación con la semiótica, porque muchos contraponen la semiótica y la hermenéutica como enemigas irreconciliables; pero creo que hay un punto de conexión, a través de la pragmática, ya que la hermenéutica misma reconoce que tiene un nivel sintáctico, otro semántico y otro pragmático, y todos ellos son aspectos de la semiótica.

FA.: ¿Cómo habría de leerse la apelación en tu obra a la analogía? ¿Cuál es el marco en el que se inscribe tu invitación a una hermenéutica analógica? 
M.B.: Yo tomo la idea de la analogía de los pitagóricos, la cual era vista no solamente como semejanza, sino, sobre todo, como proporción, como proporcionalidad. Ellos tuvieron que aprender a analogizar, a proporcionar, a equilibrar. En primer lugar, por su ideal de armonía, una armonía no estática, sino dinámica y movediza. De ella procede la idea de la virtud o areté, pues es la proporción, la moderación, el término medio. En segundo lugar, porque los pitagóricos, como descendientes de los órficos, veneraban a Dioniso y a Apolo, tratando de observar un delicado equilibrio. Adoraban a Dioniso en su forma de Zagreus, que era el descuartizado por los titanes; precisamente aquel de quien habla Nietzsche en $E l$ origen de la tragedia. También aplicaban la analogía en el eterno retorno, pues no era el retorno de lo idéntico, sino de lo análogo, de lo semejante, de lo que únicamente era igual de manera proporcional. Y, finalmente, pero lo más importante, porque, aun cuando tenían un ideal racionalista de exactitud, toparon con lo irracional. Ellos encontraron los números irracionales, y, en definitiva, iniciaron el contacto con lo infinitesimal, con lo que se va en una progresión infinita, la deriva que no tiene fin. Igualmente, encontraron lo inconmensurable, pues se toparon con la inconmensurabilidad de la diagonal. Todo eso se hizo fuente de una gran angustia cultural. Pero tanto la progresión infinita como la inconmensurabilidad la resolvieron acudiendo a la proporción, a la analogía. Sólo se alcanza de manera proporcional, analógica. No es la exactitud total, pero es la suficiente.

Esto pasó a Platón, quien, como es muy sabido, fue discípulo de pitagóricos. Él le dio plasmación en la visión jerarquizante que tuvo de la realidad. El mundo de las ideas y el mundo sublunar, y para hablar de lo suprasensible utilizó los mitos, que son también algo muy analógico. Aristóteles recogió con mucha dedicación la analogía. Es cierto, como sostiene Pierre Aubenque, que casi no utilizó la palabra "analogía», pero usó otras, como el pollachós légetai, es decir, los conceptos que se dicen de muchas maneras, que son casi todos los principales de la filosofía, y la predicación pròs hén, a saber, la que se da ordenada o jerarquizada a partir de uno que es el más propio, esto es, el analogado principal, y otros que son menos propios o analogados secundarios. Después la noción de analogía atraviesa la Edad Media; a veces aceptada, a veces negada, como por Escoto y Ockham. El univocismo impregnó el nominalismo, que pasó a la modernidad, tanto en su forma racionalista como en su forma empirista.

La analogicidad logra sobrevivir, primero en el Barroco, tiempo en el que la metáfora y la metonimia jugaron un papel muy importante, luchando por equili- 
brarse. También sobrevivió en algunos que se opusieron a la Ilustración, como Vico, y en el Romanticismo, opuesto a la Ilustración y al positivismo. También allí se luchó por el equilibrio entre lo metafórico y lo metonímico. $Y$ es lo que vemos de alguna manera en Nietzsche, pues, aunque muchos lo consideran metaforista y opuesto diametralmente a la metonimia, Luis Enrique de Santiago Guervós ha demostrado que Nietzsche no renunció del todo a la metonimia, sino que trató de sujetarla a sus justos límites. Otro que hizo pervivir el analogismo fue Ch. S. Peirce, quien asoció la analogía a la iconicidad, es decir, al signo icónico. Para él, la analogía es iconicidad, o la iconicidad es analógica. Nunca llega a la univocidad ni se desliza a la equivocidad, lo icónico se mantiene en un movedizo equilibrio entre ambas. Él asocia mucho la analogía también con la abducción, al punto de que llegó a decir que algunos lógicos que lo criticaban decían que la abducción no era sino el argumento por analogía, lo cual no era exacto. Además, Peirce asocia la analogía o iconicidad con la distinción, con el hacer distinciones precisas y fructiferas, para poder evitar la equivocidad y para aclarar los términos y conceptos.

También puede encontrarse la iconicidad y la analogía en Wittgenstein, en su teoría de los paradigmas con respecto a los cuales se guardan parecidos de familia, esto es, semejanzas, similitudes o analogías. En la actualidad, el pensamiento analógico se encuentra en autores como Bachelard y Morin, en el lado de la ciencia, y, en el lado de la literatura, en autores como Octavio Paz, que pone a la analogía como el núcleo esencial de la poesía.

FA.: ¿Cuál sería, de acuerdo con eso, lo propio y específico de una hermenéutica analógica? ¿Qué nos ofrece que la haga atendible o interesante?

M.B.: Como su nombre lo indica, la hermenéutica analógica intenta superar la distensión que actualmente se observa entre las que se pueden llamar hermenéuticas unívocas (cientificistas) y hermenéuticas equivocistas (relativistas). Las últimas proliferan ahora, en esto que se denomina tardomodernidad o posmodernidad. Se trata de evitar la rigidez de las primeras y la excesiva apertura de las segundas. Y tiene la ventaja de que en la analogía predomina la diferencia sobre la identidad; es decir, aunque está a mitad de camino entre la univocidad y la equivocidad, participa más de esta última que de aquélla. Esto le permite oscilar en difícil equilibrio entre el sentido literal y el alegórico, de modo que pueda explorar los sentidos profundos, simbólicos o alegóricos - donde los haya - sin perder el amarre del sentido literal, que es el que asegura la objetivi- 
dad que sea alcanzable. Igualmente le permite dar juego a la metáfora y la metonimia, pues el sentido metafórico enriquecerá nuestra expresión, pero será ajustado por el sentido metonímico, del que no se puede prescindir. De esta manera, una hermenéutica tal nos ayudará a buscar el sentido sin renunciar a la referencia (en contra de lo que frecuentemente se hace, pues ahora hay mucha animadversión hacia el referencialismo).

\section{Confluencias}

M.B.: Además, dado que la analogía exige el recurso a la distinción frecuente, nos ayudará a evitar los univocismos y equivocismos, con lo cual permitirá tener una interpretación sintagmática y también paradigmática; esta última es la que cala en profundidad, a la búsqueda de significados hondos y hasta ocultos del texto. Y, ya que acude a la distinción, para eso requiere del diálogo, es eminentemente dialógica. Ello nos permitirá superar ciertas dicotomías que se han considerado como irreductibles o insalvables; por ejemplo, nos ayudará a superar la dicotomía entre la descripción y la valoración (la llamada falacia naturalista) y la dicotomía de Wittgenstein entre el decir y el mostrar (de hecho, la analogicidad-iconicidad es el intento de decir lo que sólo se podría mostrar, claro que de una manera aproximativa y empobrecida: deficiente pero suficiente). Con esto puede conjuntar, en el límite, hermenéutica y ontología, para que ninguna de las dos destruya a la otra. Sobre todo, y en definitiva, nos ayudará a superar esas posturas extremas que luchan entre sí en la actualidad, sin llevar a ningún lado, y de lo cual ya está muy cansada la mayoría de los pensadores.

Es una búsqueda de confluencias que se encuentra en pensadores hispánicos, como en Ortega y Gasset y en Xavier Zubiri, según lo ha sabido señalar Jesús Conill, o en Juan David García Bacca y José Ferrater Mora, así como en los mexicanos Antonio Caso y José Vasconcelos. El pensamiento analógico ha sido trabajado en América Latina por autores como Juan Carlos Scannone y Enrique Dussel, bajo la forma de analéctica. Recientemente, Alejandro Salcedo y Greta Rivara hablan de toda una racionalidad analógica, aledaña a la hermenéutica analógica. Por cierto que viene a ser una racionalidad muy cercana a la que propone María Zambrano, es decir, tratando de conjuntar lo literal y lo simbólico, lo científico y lo poético, lo metonímico y lo metafórico. Como se ve, la analogía tiene una raigambre hispana y latinoamericana muy fuerte; es más, estuvo presente en el encuentro entre las dos culturas, en pensadores clarividentes como 
Bartolomé de las Casas, Vasco de Quiroga, Bernardino de Sahagún, Alonso de la Veracruz y Tomás de Mercado, que supieron reconocer al otro a través de la aceptación de la semejanza (no de la exigencia de la identidad), es decir, analógicamente, dejando que predominara su diferencia. Se manifestó de manera muy fuerte en el Barroco latinoamericano, en el que se ve la fusión de razas y culturas, por fuerza de la naturaleza misma, esto es, de la pasión, a pesar de que hubo innegablemente desconocimiento y opresión. Y vuelve a verse ahora, momento en el que tanto necesitamos caminos para intercomunicarnos las ideas.

F.A.: ¿Cuál es tu relación personal e intelectual con algunos de los siguientes estudiosos mexicanos de la hermenéutica: Mariflor Aguilar, Raúl Alcalá, María Herrera, José Manuel Orozco Garibay, María Rosa Palazón, Carlos Pereda, Blanca Solares y Ambrosio Velasco?

M.B.: Con Mariflor Aguilar he conversado mucho sobre Gadamer, de la que es consumada especialista. Raúl Alcalá ha hecho interesantes investigaciones sobre la hermenéutica y su relación con la ciencia, y hemos tenido un debate muy amistoso y prolongado sobre temas fundamentales de la hermenéutica, en los que disentimos pero nos ayudamos a tomarlos con más cuidado y ponderación. María Herrera ve la hermenéutica como aplicable a la filosofía política y a la filosofía de la historia, cosas que he compartido con ella. José Manuel Orozco Garibay ha explorado la hermenéutica para sus investigaciones acerca del psicoanálisis, y también, a pesar de nuestros disensos, hay una entrañable amistad. María Rosa Palazón es nuestra especialista en Ricoeur; con ella he discutido cuestiones relativas al símbolo y a la metáfora. Carlos Pereda, al igual que yo, desemboca en la hermenéutica desde la filosofía analítica; me han servido mucho las discusiones que tenido con él acerca de la verdad en la interpretación y las condiciones del diálogo. Blanca Solares me ha ayudado a clarificar mis ideas sobre el mito y la hermenéutica del mismo; en nuestras conversaciones hemos encontrado muchos caminos para aplicar la hermenéutica a este campo tan apasionante que es el del discurso religioso. Y Ambrosio Velasco utiliza la hermenéutica en las áreas de la filosofía de la ciencia y la filosofía política. Por otra parte, de Enrique Dussel, Jorge Velásquez y Gustavo Leyva he aprendido que la hermenéutica no tiene por qué ser apolítica, sino comprometida con la transformación de la realidad social.

F.A.: ¿Cuál es tu relación personal e intelectual con algunos de los estudiosos españoles de la hermenéutica: Jesús Conill, Agustín Domingo Moratalla, 
Manuel Maceiras, Andrés Ortiz-Osés, Teresa Oñate, Luis Enrique de Santiago Guervós y Eugenio Trías?

M.B.: Jesús Conill me ha enseñado a buscar una hermenéutica crítica de las instituciones, que va muy en la línea de la filosofía política y la filosofía de la cultura. De Agustín Domingo tomo la aplicación de la hermenéutica a los fenómenos sociales, lo cual la hace más útil de lo que se sospechaba. En Manuel Maceiras he encontrado una interesante aplicación de Ricoeur a las ciencias sociales. Ortiz-Osés me proporciona una complicidad con la noción de analogía mediadora, para establecer la intermediación entre los opuestos. De Teresa Oñate he recibido interesantes lecciones de cómo aplicar ideas aristotélicas en la hermenéutica, a las cuales ella les da una extraña actualidad. Asimismo, Luis Enrique de Santiago me ha manifestado la fuerte presencia de Nietzsche en la hermenéutica. Y con Eugenio Trías he debatido mucho la idea de límite analógico. También he discutido la dialectización de la analogía con Félix Duque, en la línea de los filósofos románticos como Schelling.

F.A.: ¡Cuál es tu relación personal e intelectual con Vattimo?

M.B.: A Gianni Vattimo lo conocí personalmente en septiembre de 1993, cuando estuvo en la Universidad Autónoma Metropolitana, de México D.F., en un seminario organizado por Enrique Dussel. Luego volvimos a encontrarnos en Bogotá, en un congreso iberoamericano de filosofía, en julio de 1994. Pero, sobre todo, en mayo de 2002 fuimos invitados al Congreso Internacional de Hermenéutica, en la St. Bonaventure University, New York, como speakers o conferencistas, Vattimo, Félix Duque y yo. Allí se estrechó nuestra amistad, y conversamos mucho. A mí se me había pedido que hiciera una presentación de mi propuesta de una hermenéutica analógica o analógico-icónica. Allí tuvo ocasión Vattimo de ver una síntesis de la hermenéutica analógica. Después de mi exposición, él fue el primero en pedir la palabra, y dijo que le gustaba la propuesta, porque no era violenta, sino "débil" o mediadora, aunque también presentó varias objeciones y dificultades. Por ejemplo, a él le parece que no debilito suficientemente la ontología, que todavía acepto demasiadas estructuras ontológicas; pero creo que sin ellas la hermenéutica se debilitaría demasiado y correría el peligro de trivializarse o llevar a un relativismo excesivo, si no es que al escepticismo, todo en la línea del equivocismo. Ahora Vattimo ha aceptado una invitación que le hizo la Facultad de Filosofía y Letras de la UNAM para discutir la hermenéu- 
tica analógica en octubre próximo, pues en la facultad se organiza un coloquio sobre hermenéutica analógica al que también vendrá Teresa Oñate. Espero que la discusión se reavive, para que siga beneficiándome de sus críticas. gica?

F.A.: ¿Qué desarrollos o aplicaciones ha encontrado la hermenéutica analó-

M.B.: Ya van algunos avances y utilizaciones. Ha sido aplicada a la literatura, por Caleb Olvera y Benjamín Valdivia; a la antropología (Sofía Reding, Jesús M. ${ }^{2}$ Herrera, Juan Pablo Martínez y Santos Aguirre); a la filología clásica (Víctor Hugo Méndez), al derecho (Napoleón Conde, Jesús Antonio de la Torre y Enrique Aguayo), al psicoanálisis (Luis Álvarez Colín, César Gordillo, Víctor Hugo Valdés y Fernanda Clavel), a la pedagogía (Arturo Álvarez, Samuel Arriarán y Luis Eduardo Primero) y a la política (Alejandro Salcedo, Dora Elvira García González, Remedios Álvarez y Alejandro Martínez). Hay también una búsqueda de una racionalidad analógica, por Greta Rivara Kamaji y de una referencia analógica, por María Antonia González Valerio. Igualmente, la hermenéutica analógica ha sido aplicada al estudio del símbolo y el mito (Ricardo Mazón, Rebeca Maldonado y Blanca Solares), así como a los estudios de género (Alicia Ocampo). Todo eso, en México; pero en Argentina hay un grupo trabajando esto, como en Buenos Aires, en torno a Rafael Cúnsulo, y en la Universidad del Comahue, en Neuquén, donde se aplica al multiculturalismo. También se estudia en Colombia, y en España tú mismo estás conectando la hermenéutica analógica con la hermenéutica crítica, en forma de hermenéutica crítico-analógica, y otros la están aplicando a la pedagogía (Joaquín Esteban Ortega) y a la estética (Sixto Castro). Yo veo cómo este movimiento avanza, beneficiándose de la crítica y de las aplicaciones.

\section{El ágata, el pulpo, la idea}

FA.: «Los clásicos — dice Italo Calvino- son aquellos libros que nos llegan llevando consigo la huella de las lecturas que precedieron a la nuestra y tras de sí la huella que han dejado las culturas que han atravesado [...] y nunca terminan de decir lo que quieren decir» (Italo Calvino, Por qué leer los clásicos). En la aplicación de la hermenéutica analógica a la filología, ¿qué entiendes por "clásico»?

M.B.: Aquí sigo muy de cerca a Gadamer, que tanto insistió en las nociones de tradición y de clásico. Efectivamente, estamos siempre en una tradición, y los 
mejores ejemplos de ella son los que llamamos clásicos. En esto veo una aplicación de la analogía o analogicidad, ya que si tenemos una concepción univocista de la tradición, nunca pasaremos de repetirla, de ser repetidores suyos. Aquí el clásico es para ser imitado al pie de la letra, lo cual resulta, a la postre, imposible. En el otro polo, vienen los equivocistas de la tradición, los que rompen y rasgan, los que no dejan títere con cabeza. Éstos creen que la mera labor destructiva es suficiente, y son los eternos innovadores, pero sin ton ni son. Y lo que vemos es que nunca pasan de esa labor negativa frente a la tradición. En cambio, una postura analogista $o$ analógica frente a la tradición nos hace asimilarla lo mejor que podamos, estudiarla seriamente para saber dónde ya no rinde y saber, por consiguiente, dónde se necesita innovar. Y, como en la analogía predomina la diferencia, también nos hará apostar por la innovación, aunque sin perder nunca el amarre en el trabajo serio, exigente y riguroso de estudiar la tradición misma. En esta perspectiva analogista, es clásico el que, habiendo asimilado bien la tradición, está en condiciones de aportar algo nuevo. Ha sabido reflejar la tradición misma, y él mismo se constituye en nueva tradición, o en sesgo nuevo de la tradición, en paradigma o modelo dentro de esa tradición, tanto como representante de lo anterior cuanto como representante de lo nuevo que se inicia. Y, así, un clásico no es sólo para imitar, como sucede en el univocismo, ni tampoco para denostar o tirar, como en el equivocismo, sino para seguirlo, para mantener con respecto a él lo que Wittgenstein denominaba un "parecido de familia», lo cual es muy analógico de suyo.

Y con ello me parece que se recupera la idea de Gadamer de que el clásico es una especie de universal, es una manera de universalizar. Es, ciertamente, alguien singular, particular; pero, a pesar de ello, se coloca en un rango tan abarcador, se pone en una situación de tanta lucidez, que abre los horizontes, los amplía, y con ello gana en universalidad a partir de su labor individual. Allí se combinan y se tocan lo particular y lo universal, es una cierta clave para el problema del universalismo y del particularismo, tan propio de la hermenéutica. El clásico nos enseña a ganar universalidad a partir de nuestra propia particularidad.

En un clásico, o, más sencillamente, en un buen poeta, por ejemplo, nos vemos reflejados como en un espejo. En eso consiste su universalidad. Habla de su propia alegría o de su propia tristeza, y todos encontramos reflejada nuestra propia alegría o nuestra propia tristeza. Esa es una manera de universalizar. Una manera distinta, una manera extrańa, pero válida, al fin, una especie de univer- 
sales análogos. No nos espejeamos en ellos de manera idéntica, sólo aproximada, sólo por semejanza, pero con eso nos basta.

F.A.: En varios lugares de Sombras de obras: Arte y literatura, Octavio Paz refiere la preocupación de Roger Caillois por la analogía. "Según Caillois -escribe Paz- la poesía no es un fenómeno particular del lenguaje humano sino una propiedad de la naturaleza entera. Hay una suerte de unidad y de continuidad entre el mundo físico, el intelectual y el imaginario; esa unidad es de orden formal y se constituye, a la manera de un poema, no como una serie deductiva, de significados sino como un sistema de ecos, correspondencias y analogías. Caillois no ignoraba que las piedras son piedras y que las fábulas son fábulas pero decía que, a veces, "convenía ver a las piedras como poemas y buscar en las ficciones poéticas la perennidad de las piedras...". Confrontación de las opuestas metáforas en donde, simultáneamente, se aguzan y se disipan los dos extremos del universo: el mineral y la idea» (Paz, O. 1983: «El ágata, el pulpo, la idea», en: Sombras de obras: Arte y literatura, Barcelona 1996, 243-244). Así, «desvelado por la presencia constante, a un tiempo evidente e indemostrable, de la analogía - siempre a la vista y siempre huidiza - Caillois buscó sin cesar el puente invisible que une a la piedra y a la idea" (Paz, O. 1983: "Fábula de piedra", en: Sombras de obras: Arte y literatura, Barcelona 1996, 246-247). La misma preocupación de Caillois por la analogía está presente también en la obra de Octavio Paz. Tú mismo has puesto de relieve la importancia de la analogía en Octavio Paz. ¿Hablaste alguna vez de esto con él?

M.B.: Conocí a Octavio Paz en 1975, a través de Julián Pablo Fernández, un pintor y cineasta mexicano. Sólo un par de veces nos reunimos a comer, y él me sugirió que algún día nos reuniéramos para hablar acerca del aspecto filosófico de la analogía. Nunca se pudo concretar esa cita. Pero leí lo que él había escrito acerca de la analogía como núcleo de la poesía, como lo más esencial de la misma. Me parece muy interesante lo que escribe a este propósito en otro texto recogido en Sombras de obras: Arte y literatura:

Para Caillois la piedra era música mineralizada. Sin embargo, lo que distingue al poema de todas las otras formas y organismos es precisamente lo contrario: la animación, el movimiento. El poema es un organismo rítmico, una forma en perpetuo movimiento. El poema está hecho de aspas de aire que, al girar, emiten torbellinos de sonidos que son remolinos de sentidos. 
Pero el poema no es ni música ni idea. El sentido del poema está más allá del sentido y su música no se agota en el sonido. Las ideas bailan, los sonidos piensan. Vasos comunicantes: oímos al poema con los ojos, lo pensamos con los oídos, lo sentimos con la mente. Poesía es ver y oír, pensar y sentir, todo junto. $\mathrm{O}$ más bien: es unir en un solo giro, en un oleaje rítmico, el sentir y el pensar... Pensaba todo esto (y al pensarlo lo sentía) al leer un pequeño libro que acababa de publicar Rubén Bonifaz Nuño: Tres poemas de antes (ediciones de la Universidad, MCMLXXVIII). Cada uno de estos tres poemas está compuesto, a su vez, por cuatro sonetos y tres cortas composiciones en endecasílabos y heptasílabos.

Primera alegría: esos poemas son formas sensibles que podemos ver, tocar, oír. Sobre todo oír. La poesía es un arte oral y olvidarlo, como lo olvidan algunos jóvenes poetas, es traicionarla. El tema de los poemas de Bonifaz Nuño es el tiempo y el amor, ambos fugitivos y recurrentes. La brevedad de la vida y la perennidad de la palabra: temas de Horacio y de Ronsard, temas de antes y de mañana, temas de ahora. A la manera del que se acerca a su oído, repetida maravilla, una caracola, leo los límpidos poemas de Bonifaz Nuńo y oigo, al través de cada verso y cada estrofa, los pasos del tiempo que pasa y regresa y vuelve a pasar. Al oírlos, veo cada uno de esos poemas como un árbol que arde, llama verde, en la transparencia del otoño (Paz, O. 1983: «La verde lumbre», en Sombras de obras: Arte y literatura, Barcelona 1996, 247-248).

Claro que Octavio Paz, como poeta, se inclinaba más a la parte metafórica de la analogía, a esa metáfora analógica que es la que más se hace presente en la poesía. Por eso veía a los románticos como analógicos, y es verdad en ese sentido, ya que ellos también se inclinaban mucho al lado metafórico de la analogía, a la analogía metafórica. Pero yo creo que la analogía tiene también un lado metonímico, es decir, inclinado al sentido literal, al discurso científico, al amarre objetivo de lo que, de otra manera, correría el riesgo de quedarse en lo meramente subjetivo.

En cualquier caso, Paz ha sido uno de los más grandes analogistas en el mundo, sobre todo en América Latina, en México. Él veía la analogía en el encuentro entre el hombre y la naturaleza. Así como Hölderlin decía que sólo el poeta hace habitable el mundo, y en eso lo seguía Heidegger, Paz decía que la analogía era lo que hacía habitable el mundo, porque le quitaba ese aspecto desconocido, demasiado otro, amenazador. Donde todo eran fauces y garras, miedo a los terro- 
res de la selva, el hombre puso su sello, urbanizó y se asentó. No solamente construyó su morada, sino que plasmó su firma, su marca, en toda la naturaleza (hasta el punto en que ahora vemos que está amenazada por el hombre, el hombre se ha vuelto el terror de aquello que antes era su terror).

Además de ver la analogicidad en los románticos, en su libro Los hijos del limo, Paz la ve en los barrocos, en su libro Sor Juana o las trampas de la fe. La época barroca fue analogista por la fuerte presencia en ella del símbolo, de la alegoría, de la iconicidad, por ejemplo en la emblemática. Fue analogista no sólo por sincretista, sino también porque trataba de concordar los opuestos, los extremos. Así, fue un juego de oscilación entre la metáfora y la metonimia, que eran tratadas diversamente en esos dos extremos del Barroco que fueron el culteranismo y el conceptismo. Donde más equilibrio analógico ve es en Sor Juana, que unió magistralmente ambos extremos, del conceptismo y el culteranismo, en su famoso poema "Primero sueño". Pero, así como Foucault, en su libro Las palabras y las cosas, asegura que el Quijote fue el último análogo, por ser una mezcla de genialidad y locura, de prudencia y despropósito, así también Paz da la impresión de estar de acuerdo. En su libro El arco y la lira, dice que esa novela de Cervantes fue la primera novela moderna. Porque Cervantes sabía que el Quijote era un loco, y por eso, en vez de un poema épico, escribió una novela; pero también sabía que estaba cuerdo, y por eso dejó que la novela se resolviera en poesía. Tal vez el Quijote es analógico porque supo ver su propia locura (como ocurre explícitamente al final de su vida) y la transubstanció.

\section{Horizontes de la hermenéutica}

F.A.: ¿Qué tareas prevés para la hermenéutica analógica?

M.B.: Muchas, que tienen que hacerse en equipo, en grupo. Por lo pronto, me parece que una de ellas es la de seguir estructurándose y vertebrándose interiormente, desde la misma teoría que la sustenta. Otra es, por supuesto, la de seguir aplicándose a ámbitos específicos del pensamiento, es decir, disciplinas y problemas concretos. Uno de ellos consiste en ayudarnos a esclarecer la naturaleza de una filosofía hispánica, española y americana, que puede ofrecer mucho a la filosofía universal desde su particular condición. Otro punto pendiente es el de estudiar la manera más concreta de conjuntar el intelecto y el afecto, la razón y el sentimiento, que es algo muy importante y que nos hace mucha fal- 
ta. Otro es el de la crítica de las instituciones, de modo que no solamente se aplique a la filosofía política, sino a la filosofía de la cultura, cosa que ya se ha hecho, pero sobre todo como crítica de la cultura. Éste es el legado de Nietzsche, la filosofía de la cultura como crítica de la cultura. Hay mucho que hacer y mucho que modificar en lo que se ha hecho en esa línea. Es algo en lo que encuentro un reto. Finalmente, por sólo mencionar uno de los muchos puntos pendientes, me parece que haría falta aplicar la hermenéutica analógica a la tecnología, sobre todo a las tecnologias de la comunicación, a los mass-media, ya que son los que, para bien o para mal, están dictando la orientación de nuestra cultura contemporánea.

\section{Retórica y hermenéutica}

FA.: La filosofía se ha preguntado insistentemente, sobre todo en los últimos tiempos, acerca del tipo de argumentación del que puede echar mano y del tipo de racionalidad que la anima. ¿Qué relación verías entre la hermenéutica analógica y la retórica, que encuentra en la actualidad mucho cultivo?

M.B.: Yo creo que, desde Aristóteles por lo menos, retórica y hermenéutica van muy estrechamente asociadas. Mucho de lo que tratamos ahora en la hermenéutica fue tratado por el Estagirita en la retórica (además de en el Perì hermeneias, por supuesto). En el capítulo del Tratado de hermenéutica analogica dedicado al modo de la argumentación que se propone para apoyar las interpretaciones se pone la retórica como ese modo argumentativo. En un momento en que algunos, demasiado escépticos por fuerza de la posmodernidad, ya no argumentan sino que sólo narran, creo que es importante defender la argumentación, por lo menos en esas modalidades no tan fuertes como la lógica apodíctica, pero que nos aseguren un recurso a algo objetivo. Perelman vio que esto podía hacerlo la retórica.

Además, hay una idea aristotélica, recuperada por Gadamer, que es la de virtud. La virtud como habilidad para hacer algo, cosa que se va construyendo paulatinamente y con mucho esfuerzo, a través de la teoría y sobre todo del ejercicio. Es como se veía al orador, que, además de la capacidad natural de la oratoria que ya poseía, la cultivaba y desarrollaba por medio del arte de la retórica. Es lo que ahora podemos ver en la hermenéutica como la virtus interpretativa, como la virtud de la interpretación o la aretè hermeneutiké, algo que, con el estudio y 
con la práctica, vamos construyendo en nosotros mismos para lograr buenas interpretaciones. La hermenéutica es algo que se va edificando con estudios teóricos y con ejercicios prácticos. $Y$ esto es muy parecido a la idea de prudencia o phrónesis, que Gadamer ha retomado de Aristóteles. El prudente o phrónimos es alguien que, a través del estudio y de la acción, sabe conducirse acertadamente en los casos concretos, particulares y contingentes. Es decir, sabe aplicar la ley general al caso particular. No se queda en la univocidad de la ley, pero tampoco se distiende en la equivocidad de los casos, de la pura casuística; une las dos cosas, las conecta, de modo que tenga una buena habilidad para aplicar la ley general al caso particular. Y eso es lo más hermenéutico: colocar algo particular, como es el texto, en algo más general, como es su contexto, recorriendo los grados de contextualidad o de universalidad ascendente que convenga alcanzar, para llegar a la adecuada interpretación. Es, además, algo muy analógico. No en balde se puede ver a la prudencia o phrónesis como la misma analogía puesta en práctica, hecha parte de uno mismo, transformada en vida.

FA.: En tu obra destaca el interés por la competencia cívica y democrática del individuo humano, un individuo concebido como ser social, sin dejar de ser individuo histórico y concreto. Esa ética comunicativa basada en una prudencia adquirida en el obrar, no en el cálculo de los resultados ni en la deducción a partir de principios a priori, es comunicativa pero diferente de la de Habermas. No una ética de la acción comunicativa, sino una ética de la comunicación activa y operante: la vieja ética aristotélica. Inspirados por ella estamos algunos trabajando por el establecimiento de una concepción dialógica de la gestión pública local...

M.B.: Quisiera terminar con lo siguiente. Se puede hablar de una analogía entre la prudencia o phrónesis con la hermenéutica. Antiguamente se señalaba la analogía existente entre la prudencia y la lógica. Yo quisiera señalar la analogía que existe entre la prudencia y la hermenéutica. El prudente tiene, sobre todo, la habilidad de seleccionar los medios que van a ser los mejores para conducir al fin o los fines que se ha planteado. En ese sentido, el hermeneuta prudente es el que sabe allegarse los medios necesarios para la comprensión de un texto, es decir, lo relativo al idioma en que está escrito el texto, lo relativo al estudio históricocultural del autor, lo relativo a las circunstancias en las que lo escribió y los destinatarios originales que tuvo el texto; pero también debe contar con lo que le ayude a ver cómo habla ahora el texto, a unos destinatarios que tal vez no eran los del autor, en una cultura que quizá difiere mucho de la del autor y sus desti- 
natarios, y poder hacer el texto significativo para la gente de nuestro tiempo. Asimismo, otro aspecto de la prudencia es la deliberación, que abarca la búsqueda de medios para los fines y la ponderación de los mismos (de sus pros y sus contras) para mostrarlos como conducentes, lo cual es una argumentación. Aquí se ve el doble proceso de inventio y demonstratio, esto es, el lanzamiento de una hipótesis, en nuestro caso, interpretativa, y la prueba de la misma, a través de una argumentación, la cual será, como dijimos, más bien de naturaleza retórica. Creo que con eso se ve suficientemente la analogía que guarda la hermenéutica con la prudencia o phrónesis, y, dado que la phrónesis tiene una estructura analógica, nos hace ver la oportunidad de una hermenéutica analógica.

FA.: Nada más recibir las revisiones de Mauricio Beuchot al texto de esta entrevista, Edna Rodríguez Vizcaíno, quien con dedos invisibles me ha acompañado misteriosamente desde México durante los últimos meses, me hizo llegar las líneas que reproduzco a continuación, texto que constituye un bello homenaje a la calidad humana y al infatigable trabajo filosófico desarrollado por Mauricio Beuchot en estos años.

\section{Imágenes del fragmento}

\section{I}

En la ciudad encantada un mar tormentoso lamió las piedras hace siglos, entonces su rumor atrapaba cualquier destello de vida, congelándolo en un azul grisáceo que mil años después se convertiría en huella de un fósil, caparazón de recuerdos innombrables. Pero la huella sigue ahí, en gigantescas formaciones de piedras, donde la silueta de animales, hongos, y secretos lugares reafirma la idea de que siempre habrá vestigios para narrar la inmensidad de las épocas, así como la destrucción de todo aquello que alguna vez impuso su capricho a la tierra.

\section{II}

Recuerdo que me contabas sobre la ciudad de piel, aún logro imaginar sus cavernas de sangre, la vibración de los tejidos que se rasgan, mientras la huella de una caricia les ofrece salvación. Es un infierno, desdoblar el cuerpo en búsqueda del placer más efímero, el atardecer será tan rojo como la herida que ondula cuando la noche habla de misterios que habremos de traducir. Por momentos 
vuelvo a sentir que la palabra no es mía. En realidad la escritura desapareció por bastante tiempo, no es fácil dar con el matiz, después de un silencio tan profundo no se sabe cómo iniciar. Las diferencias han sido muchas, pero tengo esa breve inspiración que se origina al aspirar el polen del secreto más absurdo.

\section{III}

También recuerda otra imagen, es de un ayer más lejano, pero no menos intensa. Era un periodo de abulia, entonces por las noches decide ir en búsqueda de algún extraño conocido, para jugar al amor libre, transgrediendo todo sentido, se entrega al rapto de una violencia en donde la piel se colorea de sangre. Por algún extraño motivo la locura acontece, las facciones de su rostro se vuelven las de un dragón, ese que en los sueños rapta a Europa, es el Dios de los abismos, pues es el hacedor del cristal con que rasgará la piel amada. El odio contra uno mismo se vuelca en una unión que no se deja atrapar por el lenguaje, es un momento de oro, la muerte se percibe dentro, no hay sorpresa cuando se corta la piel para lamer sus heridas, ella lo hace con una furia que él no alcanza a comprender, no le deja hacer lo mismo, sino que es su propia mano quien se abre el vientre. Su memoria se desvanece entre caladas, ya no sabe contar lo que ha perdido en tantos amantes, pero siempre adquiere algo de ellos, a veces es el gusto por cierta música, pues busca el arte de los cuerpos, ahí donde la estética de las cicatrices va narrando la historia de su ingreso en la noche eterna de la seducción. También suele anhelar la demencia escrita de los sabios, entonces polifacéticos amantes dejan rastros de ceniza candente para que ella se haga el amor que le han negado. No sé que sucederá con ese goce perpetuo en donde vuelca su energía, pero sé que irá a la cama para vivir de nuevo ese recuerdo que le invade la mente cuando cierra los ojos y su deseo se materializa alrededor de los sueños en que descansa su terrible duda.

\section{IV}

Tal vez esté muerta desde hace mucho tiempo, pues se ha olvidado de ese instante donde todo tuvo sentido y realidad, aunque justo en este momento su espíritu se pregunte si en realidad está pensando o sólo es la tentación que le hace creer en la lógica de su conciencia. Hay imágenes que no se olvidan, persisten incluso cuando no es posible articular coherentemente el lenguaje que usa para seducir al destino. No sabe si es un estado suspendido en la inmensidad de la 
galaxia, o sólo el eco de lo que alguna vez pudo significar el absurdo de la existencia humana. Sin embargo, es así como la palabra le brota, a través de las venas, danzando en el río de sangre que le brinda candor a su piel, pero en realidad son cuchillos que caen, se hunden y convierten en ideas que difícilmente se abandonan.

\section{$\mathbf{V}$}

La ambigüedad es un sortilegio, a través de las palabras, por encima de los pensamientos que no se concretan. En la oscuridad ha observado cómo llega la otra silueta, la de cabellos que son víboras calientes, furiosas. ¿Quién es la que surge de sus entrañas? No existen coincidencias en el atardecer de la memoria, tal vez sólo sea un diálogo sin voz. Quedarse en aquel silencio, deseando articular un lenguaje para desvanecer los fantasmas de sus cuentos. Alguien sabrá de su rostro joven, el que tuvo cuando la ciudad encantada, antes de que el mar grabara dentro de su piel la expresión de la marea constante.

\section{VI}

No ha de tocar más allá de estas paredes. La incertidumbre corroe sus huesos. Mientras apaga el cigarrillo vuelve a ser la que observa con distracción. Las pupilas comienzan a gravitar de nuevo, son azules, como el turquesa del atlántico en que ha nacido. Entonces corre hacia el espejo, esta ahí pero no se reconoce, la transfiguración provocada por los sueños absolutos ha desencadenado algo detrás de los ojos, en lo más interno de su voluntad. Lo que no ha cambiado es la eterna espera de una cama vacía, por eso siente miedo a cada amanecer, por eso prefiere el frío inédito de las sabanas ásperas.

\section{VII}

Hay un instante insospechado en que el deseo acontece. La música le transporta a través de imágenes producidas por su conciencia, entregándole a la profundidad del dolor que causa la lucidez de la nada. El suicidio lento ha dejado de ser un antídoto. Entonces sabe que también se ha cansado de escribir. Sus dedos se rehúsan a tomar la pluma una vez más. La opción última es entregarse a la locura, dejar que el destino juegue con sus días meditabundos. Esta noche descubre que en la ventana sólo puede ver su imagen, un tanto deformada, enton- 
ces aprende cómo gritar la ausencia, el desgarre de aquello que ha provocado el abandono de sí misma.

\section{VIII}

No ha sentido un arrepentimiento mortal desde hace mucho. Sufrir por lo que se hace es una estupidez cuando la tristeza debiera confinarse al conocimiento de que nunca será suficiente lo posible. En rededor de la culpa piensa en aquel sitio que para él era tan importante, la memoria recrea sus palabras, la intensidad infame de aquel tiempo. ¿Quién es él ahora? Cuestionar algo así es caer en la penetración de las noches insomnes que sucedieron entre sus cuerpos. Sin embargo acepta que la amargura no nació del castigo con que él desnudó su inocencia. Las otras cosas, esas que imaginaba cuando decía que habría de ir en búsqueda de muchas pieles, le han demostrado que el juego siempre trastoca el alma. Al final permanece sola, en la oscuridad reptante del silencio. El Arlequín se adueña de su rostro, donde nunca lo había encontrado. Ahora la vida se siente de otro modo.

\section{IX}

En cierto instante se da cuenta de que sólo porque lo sienta no significa que en verdad este ahí. Tal revelación hace que nuevas imágenes convoquen ocultos temores. La sensibilidad parece capaz de traspasar el horizonte que se le ha dado a la ocasión de ser nadie, en un territorio lírico. Arde a cada trago de saliva, muerde el papel, saborea la tinta, las ideas se desvanecen. Ha olvidado cómo pensar, cree imposible aunar sus emociones a un sistema de palabras con significados fijos. Ya no puede seguir mirando el blanco de su vida, la única opción es llenarse de aire, provocarse otros límites. Sabe que lo indispensable será dar con la tinta que surge desde adentros inconmensurables, anhela escucharla, sentir otra vez alguna furia que le descubra táctil.

\section{$\mathbf{X}$}

Pero cuando por fin cree poder decir cómo son las cosas el silencio se torna un arrozal, no puede describir los sentimientos ni circunstancias, sin embargo, logra disfrutar el abismo congelado donde se producen las imágenes fragmentarias. El presente se le escurre de las manos, el pasado es agobiante 
extrañamiento de lo que alguna vez pensó inservible, el futuro un lienzo rasgado por la apatía más fatal. La idea se aglutina lentamente, justo cuando se arroja al sin sentido de un tiempo que se presenta como ingravidez. No puede explicárselo, desconoce las razones por las cuales sigue amando a la soledad, quizá sea porque de tal manera nunca olvidará de dónde ha salido, por cuál de los túneles.

\section{XI}

En verdad cree que el sueño le ha conducido a vivir situaciones nunca previstas, como quedarse siempre en su habitación o desafiar la textura de la melodía en que se manifiesta lo incierto de lo real. La rebeldía será un constante saludo, gesto irónico que acontece ante días que su mente olvida justo al producirse, porque se abre al precipicio de la carne, al ser fruta prohibida, al negarse a los dioses absurdos.

\section{XII}

Esta muy lejos de la comprensión, querer viajar a través de sustancias alternas, volver a sentir el frágil rapto al que se ve sometida cuando la hierba induce sus sentidos a una danza vertiginosa, las ideas cruzando el papel vacío, formulación de pensamientos que buscan ir más allá de las letras, los dedos se mueven con una cadencia que es necesario seguir para poder concretar el sentido de las frases que se entrelazan, así es que se va construyendo la marea de engaños donde se cree habrá respuestas, pero sólo descubrirá una ventana tapiada, hasta el fondo.

\section{Bibliografía de Mauricio Beuchot}

1976

a) San Alberto Magno, Opuisculo de lo bello y lo bueno, trad. e introd. de M. Beuchot, Revista de Filosofia (ULA-México) 9 (1976) 99-121 y 225-248.

1977

a) San Alberto Magno, Opuisculo de lo bello y lo bueno, trad. e introd. de M. Beuchot, Cuadernos de Filosofía (UIA-México) 3 (1977) 1-48. 
1979

a) Elementos de semiótica, México [2a. ed., Xalapa 1993].

1981

a) La filosofía del lenguaje en la Edad Media, México [2a. ed., México 1991].

b) El problema de los universales, México [2a. ed. Toluca 1997].

1982

a) «Sobre el conocimiento de la materia» en: J. Esquivel (ed.), La polémica del materialismo, Madrid 1982, 146-153.

1983

a) Filosofia analitica, filosofia tomista y metafisica, México.

1985

a) Ensayos marginales sobre Aristóteles, México.

b) Mauricio Beuchot y W. Redmond, La lógica mexicana del siglo de oro, México.

c) "Aspectos epistemológicos y hermenéuticos en el Proyecto de Freud", en: M. A. Zarco (ed.), En torno al "Proyecto» de Freud, México 1985, 9-36.

1986

a) Lingüistica estructural y filosofia, México.

b) Lógica y ontologia, Guadalajara-México.

c) "La antropología filosófica de Alonso de la Vera Cruz», en AA.VV., Homenaje a fray Alonso de la Vera Cruz en el IV Centenario de su muerte (15841984), México 1986, 11-24.

d) "La teoría de la argumentación en Aristóteles», en: C. Pereda - I. Cabrera (eds.), Argumentación y filosofia, México 1986, 31-41.

e) G. W. Leibniz, Discusión metafisica sobre el principio de individuación, introd., trad. y notas de M. Beuchot, México 1986.

f) G. W. Leibniz, Investigaciones generales sobre el análisis de las nociones $y$ las verdades (1686), trad. e introd. de M. Beuchot y A. Herrera Ibáñez, México 1986. 
g) Juan de Santo Tomás, Compendio de lógica, introd., trad. y notas de M. Beuchor, México 1986.

h) Pedro Hispano, Tractatus llamados después Summule Logicales, trad. de M. Beuchot, México 1986.

i) Tomás de Mercado, Comentarios lucidísimos al texto de Pedro Hispano, trad. e introd. de M. Beuchot, México 1986.

j) "Algunos aspectos de la retórica en Fray Luis de Granada", La Ciencia Tomista 113 (1986) 127-143.

1987

a) Aspectos históricos de la semiótica y la filosofia del lenguaje, México.

b) Conocimiento, causalidad y metafisica, Xalapa.

c) Metafisica. La ontologia aristotélico-tomista de Francisco de Araújo, México.

d) Filósofos dominicos novohispanos. (Entre sus colegios y la universidad), México.

e) Mauricio Beuchot y W. Redmond, Pensamiento y realidad en fray Alonso de la Vera Cruz, México.

f) "Los universales: actualidad e importancia del problema», en: L. Benítez Grobet (ed.), Historia de la filosofia. México 1987, 17-28.

g) "San Agustín", en: Historia de la filosofia, México 1987, 29-32.

h) "Guillermo de Ockham", en: Historia de la filosofia, México 1987, 33-35.

i) "Santo Tomás de Aquino", en: Historia de la filosofia, México 1987, $37-44$.

j) «La filosofía del lenguaje en la Edad Media», Historia de la filosofia, México $1987,45-54$.

k) «Algunos profesores dominicos en la Universidad de México durante el siglo XVIl», en: M. Peset (ed.), Universidades españolas y americanas, Valencia 1987, 101-108. (reimpr. en: C. I. Ramírez - A. Pavón [comps.], La universidad novohispana: corporación, gobierno y vida económica, México 1996, 291-299).

1) Juan de Santo Tomás, Cuestiones de lógica, introd., trad. y notas de M. Beuchot, México 1987.

1988

a) Significado y discurso. La filosofia del lenguaje en algunos escolásticos españoles post-medievales, México. 
b) "La teoría semántica medieval de la supositio», en: E. González Ruiz (ed.), Filosofia y cultura medievales, México 1988, 42-51.

c) "Esquema de la filosofía cristiana en México en el siglo XX», en: G. Vargas Lozano - R. Hernández Oramas (eds.), La filosofia en México, Siglo XX, I. Aproximaciones, Tlaxcala 1988, 73-85.

d) "Érica y justicia en Tomás de Aquino", en: M. Platts (comp.), La ética a través de su historia, México 1988, 41-54.

1989

a) Los principios de la filosofia social de Santo Tomás, México.

b) Hermenéutica, lenguaje e inconsciente, Puebla.

c) «La filosofía social y política de Santo Tomás de Aquino», en: L. Benítez (comp.), Antologias para la actualización de los profesores de enseñanza media superior: filosofia II - ética y filosofia politica, México 1989, 25-30.

d) "La hermenéutica y la pragmática como herramientas del traductor", en: H. Pérez Martínez (ed.), Lenguaje y tradición en México, Zamora-México $1989,461-464$.

e) Alonso de la Vera Cruz, Libro de los elencos sofisticos, introd., trad. y notas de M. Beuchot, México 1989.

f) Alonso de la Vera Cruz, Libro de los tópicos dialécticos, introd., trad. y notas de M. Beuchot, México 1989.

g) Juan de Santo Tomás, De los signos y los conceptos, introd. y trad. de M. Beuchot, México 1989.

h) Vicente de Aragón, «Teoría del signo (México, s. XVIII)», en: Investigaciones Semióticas (Valencia, Venezuela), 7/8 (1988/1989) 12-16.

1990

a) La filosofia social de los pensadores novohispanos. La buisqueda de la justicia social y el bien común en tiempos del virreinato, México.

b) Mauricio Beuchot y Jorge Iñiguez, El pensamiento filosófico de Tomás de Mercado: lógica y economía, México.

c) «Psicología y política. La praxis cristiana como liberación en Santo Tomás de Aquino", en: R. Checa (comp.), Compromiso político y espiritualidad cristiana, México 1990, 105-116.

d) "La hermenéutica y la epistemología del psicoanálisis», en: M. Beuchot 
- R. Blanco (comps.), Hermenéutica, psicoanálisis y literatura, México 1990, 9-17.

e) «El psicoanálisis y su dimensión hermenéutica», en: Hermenéutica, psicoanálisis y literatura, México 990, 18-32.

1991

a) Metafisica y persona. Perspectivas del pensamiento de Santo Tomás de Aquino, Querétaro.

b) Estudios de historia y de filosofia en el México colonial, México.

c) Tópicos de filosofia y lenguaje, México.

d) «La teoría del significado en el último Wittgenstein y en Sto. Tomás de Aquino", en: AA.VV., Homenaje a Wittgenstein, México 1991, 61-76.

e) "La filosofía de la amistad en Sto. Tomás de Aquino", en: C. Company (ed.), Amor y cultura en la Edad Media, México 1991, 19-27.

f) «El problema del conocimiento y el realismo en Juan David García Bacca», en: AA.VV., Cincuenta años de exilio español en México, Tlaxcala 1991, 37-48.

g) "The Limits of Cultural Relativism: Metaphysics and Latin America", en: M. Dascal (ed.), Cultural Relativism and Philosophy. North and Latin America Perspectives, Leiden 1991, 159-173.

h) "Psicoanálisis y experiencia religiosa», en: AA.VV., Experiencia de Dios y psicoanálisis, México 1991, 27-36 [2a. ed. 1992].

i) "Albert de Saxe: la suposition sémantique et les noms vides", en: J. Biard (ed.), Itinéraires d'Albert de Saxe. Paris-Vienne au XIVe siècle, París 1991, 111-124.

j) «Filósofos humanistas novohispanos», en: I. Osorio Romero (ed.), La tradición clásica en México, México 1991, 109-148.

1992

a) La teologia de los dominicos novohispanos de México, en el siglo XVI, México.

b) La esencia y la existencia en la filosofia escolástica medieval. Su repercusión en la filosofia analítica actual, México.

c) Introducción a la filosofia de Santo Tomás de Aquino, México [2a. ed. México 1994].

d) La querella de la conquista. Una polémica del siglo XVI, México 1992.

e) "Comparación de la retórica con la lógica según Roberto Kilwardby», 
en: C. Company et al. (eds.), Heterodoxia y ortodoxia medieval, México 1992, 177-189.

f) «Bartolomé de las Casas ante el descubrimiento de América: su defensa de la libertad de expresión del pensamiento", en: M. de la Garza (ed.), En torno al Nuevo Mundo, México 1992, 93-104.

g) "La materia y la substancia material en Ockham", en: A. Tomasini Bassols et al. (eds.), El concepto de materia, México 1992, 9-20.

h) "La filosofía política de Carlos de Sigüenza y Góngora", en: AA.VV., América Latina: historia y destino. Homenaje a Leopoldo Zea, vol. II, México 1992, 41-47.

i) "Algunas líneas de investigación sobre derechos humanos en la filosofía jurídica española reciente», AA.VV., La universidad y los derechos humanos en América Latina, México 1992, 29-38.

j) «Introducción general: Humanismo y derechos humanos en la conquista según Fray Alonso de la Veracruz», en: A. Gómez Robledo - M. Beuchot (eds.), Fray Alonso de la Veracruz. Antologia y facetas de su obra, Morelia 1992, 37-42.

k) «El sistema lógico de fray Alonso de la Veracruz», en: ibid. 217-227.

l) «El humanismo de fray Julián Garcés, O.P.», en: AA.VV., Dominicos en Mesoamérica - 500 años, México/Colonia 1992, 39-46.

m) «Bartolomé de Ledesma y su Suma de sacramentos», ibid., 115-130.

n) "Fray Pedro de Pravia y su Tratado de la eucaristia», ibid., 131-144 [reimpr. en: C. I. Ramírez - A. Pavón (comps.), La universidad novohispana: corporación, gobierno y vida económica, México 1996, 300-310].

o) "Tomás de Mercado y su Suma de tratos y contratos", ibid., 145-161.

p) «Fray Juan Ramírez, O.P., y sus escritos en contra de la esclavitud de los indios (1595)", ibid., 163-172.

q) "Acerca de la traducción (hermenéutica y pragmática)", en: E. C. Frost (comp.), El arte de la traición o los problemas de la traducción, México 1992, 43-57.

r) "Sistema y sistematicidad en la filosofía de Santo Tomás de Aquino", en: L. Benítez - J. A. Robles (comps.), Filosofia y sistema, México 1992, 7-15.

s) "Lógica y dialéctica en fray Alonso de la Veracruz", en: M. Beuchot y B. Navarro (comps.), Dos homenajes: Alonso de la Veracruz y Francisco Xavier Clavigero, México 1992, 13-24.

t) "Algunos rasgos de la antropología filosófica en la Historia antigua de México de Francisco Xavier Clavigero", ibid., 79-83. 
u) "Los límites del relativismo cultural: la metafísica y Latinoamérica", en: M. Dascal (comp.), Relativismo cultural y filosofia. Perspectivas norteamericana y latinoamericana, México 1992, 215-232.

v) "Fray Luis de Granada: la retórica y el sentimento", Morphé 7 (1992) 131-139.

1993

a) Signo y lenguaje en la filosofia medieval, México.

b) Filosofia y derechos humanos (los derechos humanos y su fundamentación filosofica), México.

c) Mauricio Beuchot y Edgar González Ruiz, Ensayos sobre teoria de la argumentación, Guanajuato.

d) «La teoría de la verdad en Strawson», en: C. E. Caorsi (ed.), Ensayos sobre Strawson, Montevideo 1993, 7-27.

e) "Reflexiones en torno a las relaciones alma-cuerpo en Santo Tomás de Aquino", en: L. Benítez - J. A. Robles (comps.), El problema de la relación mente-cuerpo, México 1993, 13-24.

f) "Algunos aspectos de la filosofía político-social de san Vicente Ferrer", en: C. Company - A. González - L. von der Walde y C. Abellán (comps.), Voces de la Edad Media, México 1993, 49-58.

g) "Sobre el conocimiento filosófico y teológico de Dios en Eguiara y Eguren", en: E. de la Torre Villar (coord.), Juan José de Eguiara y Eguren y la cultura mexicana, México 1993, 1-28.

h) "La percepción sensible en Santo Tomás de Aquino", en: L. Benítez - J. A. Robles (comps.), Percepción: colores. México 1993, 11-29.

i) "La influencia del Renacimiento en la Colonia», en: G. Bofill Batalla (comp.), Simbiosis de culturas. Los inmigrantes y su cultura en México, México 1993, 35-64.

j) "Retórica y filosoffa en fray Luis de Granada", en: A. García del Moral - U. Alonso del Campo (comps.), Fray Luis de Granada. Su obra y su tiempo, Granada 1993, vol. I, 489-500.

k) Juan de Santo Tomás, Teoría aristotélica de la ciencia, México 1993.

1994

a) Metafisica, logica y lenguaje en la filosofia medieval, Barcelona.

b) Los fundamentos de los derechos humanos en Bartolomé de las Casas, Barcelona. 
c) El espiritu filosófico medieval, México.

d "Derechos naturales y derechos humanos en Bartolomé de las Casas y la Escuela de Salamancan, en: A. Villegas et al. (eds), Democracia y derechos humanos, México 1994, 85-99.

e) "Chrysostom Javellus (b. 1472; d. 1538) and Francis Sylvester of Ferrara (b. 1474; d. 1526)", en: J. J. E. Gracia (ed.). Individuation in Scholasticism. The Latter Middle Ages and the Counter-Reformation, 11501650, Albany, Nueva York 1994, 457-473.

f) "Filósofos novohispanos del siglo XVI», en: J. R. Sanabria - M. Beuchot, Historia de la filosofia cristiana en México, México 1994, 21-41.

g) «Francisco Javier Clavijerom, en: ibid. 107-113.

h) "Juan Benito Díaz de Gamarra y Dávalos", en: ibid., 115-127.

i) "Bernabé Navarro», en: ibid. 191-194.

j) "Adolfo García de la Sienra", en: ibid. 207-211.

k) "José Rubén Sanabria", en: ibid. 243-256.

l) "Benjamín Valdivia", en: ibid. 349-350.

m) "Conclusión", en: ibid. 359-362.

n) «Apéndice: El estudio de la tradición neolatina dentro de la filosofía novohispana. El grupo de estudios de la UNAM y la Biblotheca Philosophica Latina Mexicana", en: ibid. 363-375.

o) "Vito Alessio Robles (1879-1957)", en: AA.VV., 75 años de la Academia Mexicana de la Historia, México 1994, 31-33.

p) "Emeterio Valverde Téllez», en: ibid., 218-220.

q) "Los comienzos de la Facultad de Filosofía o Artes en la Real Universidad de Méxicon, en: AA.VV., Setenta años de la Facultad de Filosofia y Letras, México 1994, 83-96.

r) «El humanismo en el neoaristotelismo y el comunitarismo postmodernos. Algunas apreciaciones", en: AA.VV., Homenaje en memoria del Dr. Miguel Mansur, México 1994, 8-16.

s) T. de Mercado, Libro de los predicamentos o categorias, México 1994.

t) "Filosofía y retórica en Chaïm Perelman: el auditorio universal razonable», Éndoxa: Series Filosóficas 3 (1994) 301-316.

1995

a) Aristas de la filosofia medieval, Barcelona.

b) Pensamiento filosófico de San Vicente Ferrer, Valencia. 
c) Derechos humanos, iuspositivismo y iusnaturalismo, México.

d) Mauricio Beuchot y Walter Redmond, La teoría de la argumentación en el México colonial, México.

e) "Derechos subjetivos, derechos naturales y derechos humanos", en: A. Villegas et al., Laberintos del liberalismo. México 1995, 151-167.

f) "Sobre el derecho a la vida, el aborto y el proceso inicial de la vida humana. Reflexiones filosóficas", en: J. A. Torres (ed.), Dilemas morales de la sociedad contemporánea, vol. 1. México 1995, 69-78.

g) "Los márgenes de la interpretación: hacia un modelo analógico de la hermenéutican, en: M. Beuchot et al., Los márgenes de la interpretación: hacia un modelo analógico de la hermenéutica, México 1995, 10-24 [reimpr. en: M. Aguilar Rivero (coord.), Diálogos sobre filosofia contemporánea, México 1995, 159-176].

h) «La filosofía aristotélico-escolástica en la Retórica de Diego Valdés», en: C. Finzi - A. Morganti (eds.), Un francescano tra gli Indios. Diego Valadés e la "Rhetorica Christiana", Rimini 1995, 197-205.

i) "Filología clásica y hermenéutica", en: E. Cohen (ed.), Aproximaciones. Lecturas del texto, México 1995, 41-61.

j) "Los autos de Sor Juana: tres lugares teológicos», S. Poot Herrera (ed.), Sor Juana y su mundo. Una mirada actual, México 1995, 353-392.

k) "La verdad hermenéutica y pragmática en Karl-Otto Apel», en: S. Arriarán - J. R. Sanabria (comps.), Hermenéutica, educación y ética discursiva (en torno a un debate con Karl-Otto Apel), México 1995, 55-66.

1) "Libertad y libre albedrío en Santo Tomás", en: AA.VV., Sanctus Thomas de Aquino doctor hodiernae humanitatis, Ciudad del Vaticano 1995, 439-446.

m) J. Zapata y Sandoval, Disceptación sobre justicia distributiva y sobre la acepción de personas a ella opuesta, Segunda parte, México 1995.

n) Escolástica ibérica postmedieval. Algunas teorias del signo, selección de textos, introducción y traducción de M. Beuchot, Maracaibo-Caracas 1995.

o) "Cicerón: entre el arte y la habilidad natural de la retórica», Noua Tellus 13 (1995) 59-69.

a) Filosofia y ciencia en el México dieciochesco, México.

b) Posmodernidad, hermenéutica y analogia, México. 
c) Interpretación y realidad en la filosofía actual, México.

d) Historia de la filosofia en el México colonial, Barcelona.

e) «La filosofía en el México colonial», en: G. Marquínez Argote - M. Beuchot (dir.), La filosofia en la América colonial, Bogotá 1996, 21-52.

f) "Some Traces of the Presence of Scepticism in Medieval Thought", en: R. H. Popkin (ed.), Scepticism in the History of Philosophy. A Pan-American Dialogue, Dordrecht 1996, 37-43.

g) «Some Examples of Logic in New Spain (Sixteenth-Eigtheenth Century)",en: I. Angelelli - M. Cerezo (eds.), Studies on the History of Logic. Proceedings of the III Symposium on the History of Logic, Berlín/Nueva York 1996, 215-228.

h) "Algunas doctrinas filosóficas de Francisco Xavier Alegre sobre el hombre, el derecho y la guerra justa», en: L. Olivé y L. Villoro (eds.), Filosofia moral, educación e historia. Homenaje a Fernando Salmerón, México 1996, 507-517.

i) "Algunas fuentes de la filosofía social de fray Ramón Casaus, O.P., catedrático de la universidad y autor del Anti-Hidalgon, en: E. González González (coord.), Historia y universidad. Homenaje a Lorenzo Mario Luna, México 1996, 587-594.

j) «El universo filosófico de Sor Juana», en: M. Beuchot - M. Peña, M. Andueza, Homenaje a Sor Juana Inés de la Cruz (1695-1995), México 1996, 9-19.

1997

a) Etica y derecho en Tomás de Aquino, México.

b) Implicación, falacia y argumento, Guadalajara-México.

c) Tratado de hermenéutica analógica, México.

d) Perfiles esenciales de la hermenéutica, México.

e) El núcleo ontologico de la interpretación (la substancia y el lenguaje), Guadalajara-México.

f) "Hermenéutica y metafísica", en: J. R. Sanabria - M. Beuchot (comps.), Algunas perspectivas de la filosofia actual en México, México 1997, 13-23.

g) "Eugenio Trías y Hermes: límites, analogía y mestizaje», en: ibid. 271-288.

h) "El sentido del dolor en la hermenéutica mística de Ramon Llull", en: I. Cabrera - E. Nathan (comps.), Religión y sufrimiento, México 1996, 119-125. 
i) "Le carré de Saint Anselme et le carré sémiotique de Greimas", en: E. Landowski (ed.), Lire Greimas, Limoges 1997, 15-27.

j) "The Philosophical Discussion of the Legitimacy of the Conquest of Mexico in the Sixteenth Century", en: K. White (ed.), Hispanic Philosophy in the Age of Discovery, Washington 1997, 31-44.

k) "El problema y dilema de la tolerancia: noción histórica y filosófica», en: AA.VV., Dilemas morales de la sociedad contemporánea, vol. 2., México $1997,57-76$.

1) "Signo y semiótica en el siglo de oro español», en: C. González Ochoa (comp.), Filosofia y semiótica. Algunos puntos de contacto, México 1997, 71-91.

m) «La vida y la obra de Bartolomé de las Casas como paradigma de historiador que reconoce la identidad latinoamericana en el indígena», en: $\mathrm{R}$. Martínez Lacy (comp.), Historia y hermenéutica, México 1997, 43-57.

n) «La argumentación en la hermenéutica. El paradigma de Perelman», en: R. Alcalá (comp.), Hermenéutica, retórica y argumentación, México 1997 , 23-37.

o) «Presencia de Nebrija en la Nueva España: Julián Garcés y Bartolomé de las Casas", en: I. Guzmán Betancourt - E. Nansen Díaz (eds.), Memoria del coloquio La obra de Antonio de Nebrija y su recepción en la Nueva España. Quince estudios nebrisenses (1492-1992), México 1997, 145-151.

p) «La hermenéutica en S. Agustín y en la actualidad», en: E. Lazcano (ed.). Homenaje a, Madrid 1997, 139-156.

q) "Los derechos humanos y el fundamento de su universalidad", en: J. Saldaña (coord.), Problemas actuales sobre derechos humanos. Una propuesta filosófica, México 1997, 51-60.

r) "Vindicación del pensamiento analógico", en: J. R. Sanabria y J. M. Mardones (comps.), ¿Tiene la analogia alguna función en el pensar filosófico?, México 1997, 143-179.

s) «Sobre la hermenéutica y la analogía. Respuesta a Raúl Alcalá», en: ibid. 205-218.

t) «Sobre la fundamentación de los derechos humanos en la ética discursiva", Philosophica (Valparaíso, Chile) 19/20 (1996/1997) 185-191.

u) «Panorámica de temas en la filosofía novohispana", en: M. T. Ramírez (coord.), Filosofia de la cultura en México, Morelia/México 1997, 69-80. 
v) J. J. de Eguiara y Eguren, La filosofia de la trascendencia (Selectae Dissertationes Mexicanae, tract. I, dissert, 1-2), introd., trad. y notas de M. Beuchot, México 1997.

w) "Réplica a Ángel Francisco Hernández», Isonomia (ITAM, México) 6 (1997) 179-182.

1998

a) Beuchot, M. - Sobrino, M.Á., Historia de la filosofia. Desde la antigüedad hasta la postmodernidad, México.

b) La retórica como pragmática y hermenéutica, Barcelona.

c) "Los derechos humanos en la filosofía analítica: Ronald Dworkin", Tópi$\cos 15$ (1998) 31-42.

d) «Interpretación, analogía e iconocidad», en: M. Beuchot (coord.), La voz del texto. Polisemia e interpretación. Memoria. Primera Jornada de Hermenéutica, México 1998, 25-38.

e) Perfiles esenciales de la hermenéutica, México [2a. ed., 2000; 3a. ed., 2002].

1999

a) Las caras del simbolo: el icono y el idolo, Madrid.

b) Los Derechos Humanos. Historia y Filosofia, México [2." ed. 2001].

c) Arriarán, S. - Beuchot, M., Virtudes, valores y educación moral. Contra el paradigma neoliberal, México.

d) Arriarán, S. - Beuchot, M., Filosofia, neobarroco y multiculturalismo, México.

2000

a) «Perspectivas futuras de la retórica en su conexión con la hermenéutican, Éndoxa: Series Filosóficas 12 (2000) 521-540.

2001

a) Sor Juana, una filosofia barroca, México.

b) "Retórica y discurso analógico", en: H. Beristáin (ed.), El horizonte interdisciplinario de la retórica, México 2001, 291-301.

c) "Hermenéutica, analogía, metonimia y metáfora", en: M. Beuchot y A. Velasco (eds.), Perspectivas y horizontes de la hermenéutica en las huma- 
nidades, el arte y las ciencias. Memoria. Tercera Jornada de Hermenéutica, México 2001, 77-85.

2002

a) Los principios de la filosofia de santo Tomás. Lineas generales del pensamiento sociopolítico de santo Tomás de Aquino, México.

b) La hermenéutica en la Edad Media, México.

c) Universalidad e individuo. La hermenéutica analógica en la filosofia de la cultura y en las ciencias humanas, Morelia.

d) "El pensamiento analógico en las filosofías analítica y pragmática», Diánoia 48 (2002) 25-36.

e) "Conflicto cultural», en: Conill, J. (coord.), Glosario para una sociedad intercultural, Valencia 2002, 57-61.

2003

a) Hermenéutica analógica y del umbral, Salamanca.

b) Beuchot, M. - Primero Rivas, L.E., La hermenéutica analógica de la pedagogía de lo cotidiano, Primero Editores, México.

2004

a) Hermenéutica, analogía y símbolo, México.

b) «Interculturalidad", en: Ortiz-Osés, A. y Lanceros, P. (eds.), Diccionario interdisciplinar de Hermenéutica, Bilbao ${ }^{4} 2004,265-269$.

2005

a) Arenas-Dolz, F. - Beuchot, M. (eds.), Diez palabras clave sobre hermenéutica, Estella [en prensa].

b) Arenas-Dolz, F. - Beuchot, M., El taller de la hermenéutica. Ética, retórica y educación, México [en prensa].

\section{Bibliografía sobre Mauricio Beuchot}

1989

a) Peña, L., "Sobre cuatro obras de Mauricio Beuchot", Espiritu 38 (1989) 61-69. 
1991

a) Romero Baró, J. M., "Lógica y ontología en la epistemología de Mauricio Beuchot", Espiritu 40 (1991) 121-129.

1992

a) Valdivia, B., "Beuchot, Mauricio», en: F. Jacob (dir.), Enciclopédie universale de la Philosophie, vol. III: A. Mattéi (dir.), Dictionnaire des oeuvres Philosophiques, t. 2, París 1992, 2030.

1993

a) Carrión Wam, R., "Una experiencia de lectura: notas para la constitución de un glosario de Algunas teorias del signo de la escolástica ibérica postmedieval de Mauricio Beuchot", en: II Coloquio Iberoamericano sobre Pensamiento Colonial, (Valencia-Venezuela), Caracas 1993, 51-55.

b) Sanabria, J. R., Cristianismo y filosofia en México, México 1993, 44-46.

1994

a) Ibargüengoitia, A., Filosofia social en México. Siglos XVI al XX. Sintesis histórico-crítica, México 1994, 181-183 y 198.

b) Valdivia, B., "Mauricio Beuchot», en: J. R. Sanabria (ed.), Historia de la filosofia en México, México 1994, 195-202.

1995

a) Aguayo Cruz, E. I., "La filosofía del lenguaje de Mauricio Beuchot», Logos (ULSA, México) 65 (1994) 11-34.

b) Aguayo Cruz, E. I., "El concepto de persona en la filosofía de Mauricio Beuchot", Estudios (ITAM, México) 41 (1995) 85-94.

c) Ibargüengoitia, A., Suma filosófica mexicana (Resumen de Historia de la Filosofia en México), México ${ }^{3} 1995,230-231$.

1996

a) Ibargüengoitia, A., "Filosofía y sociedad en México en el siglo XX", Revista de Filosofía (UIA, México) 29 (1996) 107-108. 
1997

a) Acosta Beltrán, J. H., Fundamentación filosófica de los derechos humanos en Mauricio Beuchot, México.

b) Aguayo, E., Pensamiento e investigaciones filosóficas de Mauricio Beuchot, México.

c) Alcalá Campos, R., «La hermenéutica analógica de Mauricio Beuchot», en: J. R. Sanabria y J. M. Mardones (comps.), ¿Tiene la analogía alguna función en el pensar filosoffico?, México 1997, 181-203.

d) Cabrera, L., La respuesta de M. Beuchot a la posmodernidad [tesis de licenciatura presentada en la UNIVA, Guadalajara, Jal, México (agosto 1997) y en la Universidad Pontificia de México, D.F., (diciembre 1997)].

d) Hernández, A., "¿Fundamentación o protección de los derechos humanos? Las tesis de Bobbio y de Beuchot", Isonomía 6 (1997) 171-178.

e) Guy, A., La philosophie en Amérique Latine, París 1997, 98.

f) Reding Blase, S., "Analogía y teoría de la historia”, Anámnesis 7/2 (1997) 196-197.

g) Santos Aguilera, N., La relación entre la filosofia tomista y la filosofia analitica. Ideas de Mauricio Beuchot, México [Número especial de Analogía Filosófica, 1].

1998

a) Acosta Beltrán, J.H., "La noción de derechos humanos como derechos naturales en el pensamiento de Mauricio Beuchot», en: M. P. Irigoyen Tronconis (comp.), Iusnaturalistas y Iuspositivistas mexicanos (ss. XVI-XX), México 1998, 235-256.

b) Portilla Hinojosa, La dignidad de la persona humana segun Mauricio Beuchot [Trabajo de bachillerato en Filosofía presentado en la Universidad Pontificia de México (abril 1998)].

c) Sanabria, J.R. (ed.), Diálogos con Mauricio Beuchot sobre la analogía, México.

1999

a) Alcalá Campos, R., Hermenéutica, analogía y significado. Discusión con Mauricio Beuchot, México.

b) Carrillo Canán, A. (comp.), Hermenéutica, analogía y diálogo intercultural, México. 
c) Herrera Aguilar, J.M., Antropologia filosófica y analogía en Mauricio Beuchot, México [Número especial de Analogía Filosófica, 5].

d) Reding Blase, S., Antropología y analogía, México.

2000

a) Álvarez Colín, L., Hermenéutica analógica, símbolo y acción humana, México.

b) Gutiérrez Robles, A. (comp.), La hermenéutica analógica: hacia un nuevo orden de racionalidad. Círculo de HermenéuticalDiálogos con Mauricio Beuchot, México.

c) Matamoros Franco, N.M., Hermenéutica analógica, comunicación y empatía, México [Número especial de Analogía Filosófica, 7].

d) Olvera Romero, C., Hermenéutica analógica y literatura, México/Cali.

e) Salcedo Aquino, A., Hermenéutica analógica, pluralismo cultural y subjetividad, México.

f) Sobrino Ordóñez, M.A. - Velázquez Mejía, M. (eds.), Analogía e interpretación filosófica, Toluca.

g) Torre Rangel, J.A. de la, "Racionalidad analógica: un modo de acceso al iusnaturalismo histórico", Revista de Investigaciones Jurídicas [Escuela Libre de Derecho, México, D.F.] 22 (2000) 411-428; también en: Vargas, A. (comp.), Derechos humanos, filosofia y naturaleza, México 2000, 37-54.

2001

a) Aguayo, E., La hermenéutica filosófica de Mauricio Beuchot, México.

b) Arriarán, S. - Hernández, E. (comps.), Hermenéutica analógica-barroca y educación, México.

c) Conde Gaxiola, N., Hermenéutica analógica. Definición y aplicaciones, México.

d) García González, D.E., Hermenéutica analógica, política y cultura, México.

e) Hernández Alvídrez, E., Hermenéutica, educación y analogía. Fundamentos hermenéuticos de una educación mediante la lectura de textos literarios, tesis de Maestría en Filosofía de la Cultura, Universidad Michoacana - Universidad Intercontinental, México.

f) Peregrina Mancilla, C., La hermenéutica analogica y su fundamentación ontológica en Mauricio Beuchot, México [Número especial de Analogía Filosófica, 9]. 
g) Salcedo Aquino, A., Multiculturalismo: orientaciones filosóficas para una argumentación pluralista, México.

h) Silar, M., Hermenéutica analógica y semiótica en Mauricio Beuchot: un encuentro fecundo, México [Número especial de Analogía Filosófica, 8].

i) Torre Rangel, J.A. de la, Derechos humanos desde el iusnaturalismo histórico analógico, México.

2002

a) Álvarez Balandra, A.C., Hermenéutica analógica y procesos educativos, México [Número especial de Analogía Filosófica, 10].

b) Álvarez Colín, L., El universo simbólico de la familia. Un estudio de psicología hermenéutica, México.

c) Aspe Armella, V., Las aporias fundamentales del periodo novohispano, México.

d) Conde Gaxiola, N., Dos aplicaciones de la hermenéutica analógica: el urbanismo y el turismo, México.

e) Gordillo Pech, C., Hermenéutica analógica, psicoanálisis y lenguaje. Prolegómenos a la aporía de la técnica de interpretación, México [Número especial de Analogía Filosófica, 11].

f) Luján Salazar, E. (comp.), Hermenéutica analógica: una propuesta contemporánea. Diálogos con Mauricio Beuchot, Aguascalientes.

g) Mazón Fonseca, R., La hermenéutica analógica y el mito, México.

h) Méndez Aguirre, V.H., ¿Filantropia divina en la ética de Aristoteles? Lectura desde la hermenéutica analógica, México.

i) Valdés Pérez, V.H., Cultura y psicoanálisis. Hermenéutica del concepto de cultura en Freud, Morelia.

j) Valdés Pérez, V.H., (coord.), Hermenéutica analógica y filosofia de la cultura, México.

2003

a) Álvarez Colín, L. (comp.), Hermenéutica analógica, símbolo y psicoanálisis, México.

b) Álvarez Santos, R., Hermenéutica analógica y ética, México.

c) Arenas-Dolz, F., Hacia una hermenéutica analógico-crítica, México [Número especial de Analogía Filosófica, 12]. 
d) Arenas-Dolz, F., «Ética, analogía e iconicidad: Jesús como ícono del Padre y el hombre como imagen de Dios", en: Actas del XI Simposio de Teologia Histórica "La Encarnación: Cristo al encuentro de los hombres» (Valencia 6-8 marzo 2002). Valencia 2003, 339-352.

e) Conde Gaxiola, N., Hermenéutica analógica, humanismo e historia, México.

f) González Valerio, M.A. - Valdés Pérez, V.H. (comps.), Hermenéutica analógica y pluralidad cultural, Morelia.

g) Gordillo Pech, C, Tiempo, analogia lingüistica y significacion. Antecedentes y perspectiva de la historicidad en la técnica psicoanalitica, México.

h) Herrera, J.J., Hermenéutica, analogia y ontologia en Mauricio Beuchot, México.

i) Hurtado Pérez, G. (ed.), Hermenéutica analógica. Aproximaciones y elaboraciones, México.

j) Martínez de la Rosa, A., La hermenéutica analógica y la emancipación de América Latina, México.

k) Martínez Hernández, J.P., Antropología filosófica en Mauricio Beuchot, Morelia.

1) Ocampo Jiménez, A., La hermenéutica analogica en el análisis de los feminismos en la postmodernidad, México [Número especial de Analogía Filosófica, 13].

2004

a) Arenas-Dolz, F., «RetorÉtica. Actualidad de la hermenéutica analógicocrítica», en: I. Murillo (ed.), Filosofia práctica y persona humana, Salamanca 2004, 625-634. 